\title{
London super-lab opens under cloud of Brexit
}

\section{Research begins at the unabashedly international Francis Crick Institute.}

\section{BY EWEN CALLAWAY}

C $\boldsymbol{T}_{\mathrm{t}} \mathrm{t}$ is amazing, isn't it," says Paul Nurse, as he stands on a bridge overlooking the grand atrium of the new Francis Crick Institute in London. Light floods in from the building's cathedral-like entrance. "I can't quite believe it's here."

Nurse, the institute's founding director, and his ten lab members are among the first researchers to begin working at the Crick, which opened to the media on 1 September.

The UK government and the Crick's other funders have gambled $£ 700$ million (US\$927 million) on the institute, in the hope that it will attract some of world's brightest young biomedical researchers and catalyse a boom in the UK life-sciences economy.

The building will eventually house 1,500 scientists and support staff, making it Europe's largest single-site biomedical institute. They will study a broad portfolio of biomedical research, from immunology to cancer genetics.

The 93,000-square-metre glass and steel temple looms over the neighbouring British Library, the largest public structure built in Britain in the twentieth century. But looming over the Crick is the prospect of Brexit.

\section{WORLD STAGE}

The UK vote on 23 June to leave the European Union poses a range of uncertainties for UK researchers, from access to European funding to the ease of moving between EU countries. "Our vision is to be a major research institute of great significance on the world stage," says Nurse. "Internationalism is absolutely in our DNA."

The Crick's first researchers, who began arriving in mid-August, come mostly from two institutes in London: the National Institute of Medical Research, run by the Medical Research Council, and the London Research Institute, run by Cancer Research UK.

The plan is for the Crick to house a growing and ever-changing roster of young group leaders, who will spend up to 12 years there.

More than half of the Crick's current postdocs are from EU countries other than the United Kingdom, Nurse notes, and limits to freedom of movement for EU workers could make it harder to recruit. If Britain does not secure access to EU research-funding

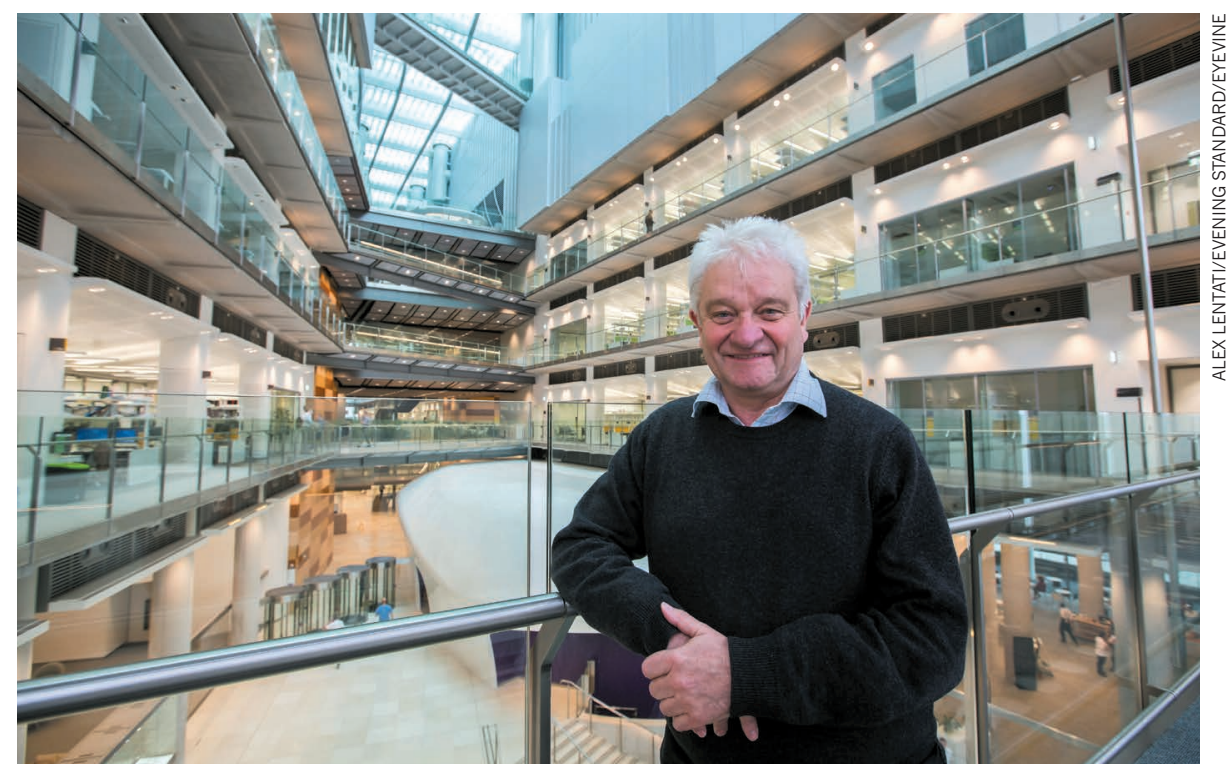

Paul Nurse says that internationalism is in the DNA of London's Francis Crick Institute.

programmes, that could also limit funding for the Crick's scientists.

Jernej Ule, a molecular biologist at University College London who will spend three years at the Crick, is emblematic of Nurse's international vision. Ule is a native of Slovenia

"It portrays the exact opposite sentiment that some people feel Brexit represents." and did his $\mathrm{PhD}$ and postdoctoral work in the United States. His lab, which studies how changes in gene expression influence motor neuron disease and other neural conditions, includes scientists from Spain, Italy, France, Germany and the United Kingdom. "For me to recruit the best people, I need to have a capacity to throw a net very broadly," he says.

Ule also receives EU funding. After he arrived in the United Kingdom, he won a grant from the European Research Council (ERC) in 2007 to study RNA regulatory networks in neurons, then a nascent area of research.

"Having the chance to apply for European funding at this top level is crucial to give us this independence of thinking in very new directions," he says. "Without the ERC I wouldn't be where I am right now."

$\mathrm{He}$ and several other scientists who have begun working at the Crick say that the institute's mission is even more essential in the wake of the Brexit vote.

"It's almost like we have the Crick in spite of Brexit," says Matthew Swaffer, a postdoc in Nurse's lab. "I feel like it portrays the exact opposite sentiment that some people feel Brexit represents.'

Swaffer's colleague Tiffany Mak, a first-year $\mathrm{PhD}$ student, joined the Crick in part because of its allure as a mecca for researchers from a wide variety of disciplines - and that has not diminished. "This project puts so much emphasis on bringing people from all sorts of backgrounds together. Hopefully it will act as a hub and not let politics get in the way of science and collaboration."

The Crick is likely to experience many of the same anxieties over Brexit as other UK research institutions, says Kieron Flanagan, a science-policy researcher at the University of Manchester.

But the institute's high profile - some have described it as "too big to fail" - could even buffer it from some Brexit worries, such as the ability to continue to recruit top scientists from Europe, he says. "They may have fewer problems than the university in the middle of nowhere in attracting people, but there will still be that concern there." - 